\title{
STRATEGI GURU DALAM MENINGKATKANKREATIVITAS ANAK

\author{
USIA TAMAN KANAK-KANAK
}

\section{Kori Makulua}

\begin{abstract}
Child developmentvariesnaturally; such as the progress on talent, enthusiasm, creativity, emotional maturity, personality, and physical and social circumstances. Each child also has a limited ability to learn is inherent himself, to think creatively and productively. Children will be active in accordance with the interests and potential of themselves, so the development of children's creativity should be started in early childhood such as Education Early Childhood (ECD) non-formal such as Daycare, Play Group or ECD Formal. To achieve optimal development of children's creativity for children in Kindergarten, then the strategy of teachers in the learning activity is necessary, so that the child will be stimulated to think and act creatively. Regarding the strategy of teachers, there are some things that need to be considered by the teacher, including: factors of child development in Kindergarten, mastery learning strategy concept, has a creative potential within themselves, so that the creative potential that is, a teacher can do a learning activity for children ages in Kindergarten through activities that are packaged in the form of a game. It is hoped that such strategies of teachers can enhance the creativity of children of Kindergarten age.
\end{abstract}

Keywords : Strategy, Teacher, Child, Creativity, Personality, Potential

\begin{abstract}
Abstrak
Secara alamiah, perkembangan anak berbeda-beda, baik dalam bakat, minat, kreativitas, kematangan emosi, kepribadian keadaan jasmani dan sosialnya.Selain itu juga setiap anak memiliki kemampuan terbatas dalam belajar yang inheren, dalam dirinya untuk dapat berpikir kreatif dan produktif. Anak akan beraktivitas sesuai dengan minat dan potensi yang dimiliki dirinya, sehingga pengembangan kreativitas anak harus dimulai sejak anak usia dini baik dalam pendidikan PAUD non formal (TPA, KB) maupun PAUD Formal (TK). Untuk mencapai pengembangan kreativitas anak yang optimal bagi anak usia taman Kanak-Kanak, diperlukan strategi guru dalam pembelajaran, sehingga anak akan terangsang untuk berpikir kreatif. Ada beberapa hal yang perlu diperhatikan oleh guru, diantaranya: faktor perkembangan anak Taman Kanak-Kanak, menguasai konsep strategi pembelajaran, memiliki potensi kreatif dalam diri, sehingga dengan potensi kreatif itulah, seorang guru dapat melakukan aktivitas pembelajaran untuk anak usiaTaman KanakKanak, melalui aktivititas atau kegiatan-kegiatan yang dikemas dalam bentuk permainan. Diharapkan dengan strategi guru yang demikian dapat meningkatkan kreativitas anak usia taman kanak-kanak.
\end{abstract}

Kata Kunci : Strategi Guru dan Kreativitas, kepribadian, potensi 


\section{Pendahuluan}

Taman Kanak-Kanak merupakan salah satu pendidikan prasekolah yang ada di jalur pendidikan sekolah. Pendidikan prasekolah adalah pendidikan untuk membantu pertumbuhan dan perkembangan jasmani dan rohani anak di luar lingkungan keluarga sebelum memasuki pendidikan dasar. ${ }^{1}$ Usaha ini dilakukan supaya anak usia 4-6 tahun lebih siap mengikuti pendidikan selanjutnya. Sebagaimana terdapat dalam Garis-Garis Besar Program Kegiatan Belajar Taman Kanak-Kanak (GBPKBTK, 1994) bahwa Taman Kanak-Kanak didirikan sebagai usaha mengembangkan seluruh kepribadian anak didik dalam rangka menjembatani pendidikan dalam keluarga dan pendidikan disekolah. ${ }^{2}$ Adapun yang menjadi tujuan program kegiatan belajar anak Taman Kanak-Kanak adalah untuk membantu meletakan dasar ke arah perkembangan sikap, pengetahuan, keterampilan dan daya cipta yang diperlukan oleh anak didik dalam menyesuaikan diri dengan lingkungannya dan untuk pertumbuhan dan perkembangan selanjutnya.

Diakui atau tidak, manusia memiliki potensi kreatif sejak awal ia diciptakan. Hal ini dapat dilihat pada awal perkembangannya, seorang bayi dapat memanipulasi gerakan ataupun suara hanya dengan kemampuan pengamatan atau pendengarannya.Ia belajar mencoba, meniru, berkreasi dan mengekspresikan diri sesuai dengan gayanya sendiri yang khas dan unik. Hal ini menunjukkan bahwa pada dasarnya anak telah memiliki jiwa kreatif.

Dengan kreativitas alami yang dimilikinya,anak akan senantiasa membutuhkan aktivitas yang sarat dengan ide kreatif. Secara alami rasa ingin tahu dan keinginan untuk mempelajari sesuatu itu telah ada dan merupakan anugerah Tuhan seperti yang telah dikemukakan pada awal bagian ini.Maka secara naturalpun anak memiliki keberanian untuk mempelajari sesuatu menurut caranya sendiri.Oleh karena itu Taman Kanak-Kanak merupakan salah satu jalur pendidikan anak usia dini yang siap mengembangkan kreativitas anak. Untuk mengembangkan kreativitas yang dimiliki oleh anak, bukan hanya menjadi tanggung jawab orang tua/orang dewasa lainnya, tetapi juga yang tidak kalah penting peranannya adalah guru dalam hal ini guru Taman Kanak-Kanak. 
Kreativitas yang harus dikembangkan oleh guru adalah daya cipta yang mulamula timbul untuk merangsang anak didik ke arah penyajian kembali, penemuan kembali (rediscovery), yang lambat laun akan menjurus ke arah penemuan yang baru dan timbulnya problem baru. Selanjutnya pada pasal 28b pasal 2, dinyatakan bahwa setiap anak berhak mengembangkan diri melalui pemenuhan kebutuhan dasarnya, berhak mendapatkan pendidikan dan memperoleh manfaat dari ilmu pengetahuan dan teknologi, seni dan budaya demi meningkatkan kualitas hidupnya dan demi kesejahteraan umat manusia. ${ }^{3}$

Berkaitan dengan hal tersebut di atas, maka proses pendidikan harus memanusiakan manusia.Pendidikan tidak hanya terbatas berperan pada pengalihan ilmu pengetahuan saja, namun dalam undang - undang No.20 tahun 2003 tentang sistim pendidikan nasional yang menyebutkan bahwa pendidikan memiliki fungsi mengembangkan kemampuan dan membentuk watak serta peradaban bangsa yang bermartabat dalam rangka mencerdaskan kehidupan bangsa, bertujuan untuk berkembangnya potensi peserta didik agar menjadi manusia yang beriman dan bertakwa kepada Tuhan Yang Maha Esa, berahlak mulia, sehat, berilmu, cakap, kreatif, mandiri, dan menjadi warga negara yang demokratis serta bertanggungjawab. ${ }^{4}$ Dari fungsi dan tujuan pendidikan ini diharapkan manusia Indonesia adalah manusia yang berimbang antara segi kognitif, efektif, dan psikomotor.

Untuk mempertahankan daya kreatif, para pendidik harus memperhatikan sikap natural anak yang sangat menunjang tumbuhnya kreativitas. Dalam upaya mengembangkan kreativitas ini, hendaknya dilakukan semenjak usia dini, sebab pada masa ini individu memiliki peluang yang sangat besar untuk dapat mengembangkan potensi-potensi yang dimilikinya.Pertanyaan yang muncul adalah mengapa kreativitas penting diperhatikan dan apa peranannya dalam kehidupan seseorang? Kreativitas seperti yang telah dinyatakan oleh David Champbell, dalam Taufig, mengatakan bahwa kreativitas mempunyai peran yang sangat bagi kesuksesan hidup sesorang. ${ }^{5} \mathrm{Hal}$ itu disebabkan karena di dalam kreativitas tergambar peran penting penentu kesuksesan.Demikian halnya pada 
anak, peran kreativitas membentuk pola atau perilaku anak dalam hidup kesehariannya.

Pengembangan kreativitas anak usia dini bukan hanya menjadi tanggungjawab orang tua, tetapi juga menjadi tanggungjawab guru dan lingkungan dimana anak itu berada. Dalam kaitannya dengan strategi guru disekolah, implementasinya terletak dalam proses pembelajaran yang dilakukan di dalam kelas maupun di luar kelas. Pelaksanaan pembelajaran merupakan suatu hal yang paling penting dalam kegaiatan pendidikan.Pada tahap inilah materi yang menjadi tujuan pendidikan disampaikan atau diberikan kepada peserta didik. Oleh karenanya, pelaksanaan pembelajaran perlu dirancang dan diformat dengan sebaik-baiknya, supaya apa yang disampaikan dapat terserap dan dipahami dengan mudah, serta memperoleh hasil yang maksimal, karena pengembangan kreativitas menjadi bagian dari perubahan perilaku yang diharapkan.

Pertanyaannya adalah bagaimana cara atau strategi yang dipakai oleh guru untuk mengembangkan kreativitas anak usia Taman Kanak-Kanak? Pertanyaan ini menjadi fenomena yang sangat menarik, sekaligus memberikan inspirasi untuk mengkajinya dalam tulisan ini.

\section{Pembahasan}

\subsection{Pengertian Strategi Belajar-Mengajar}

Secara umum strategi mempunyai pengertian suatu garis-garis besar haluan untuk bertindak dalam usaha mencapai sasaran yang telah ditentukan. Jika dihubungkan dengan belajar-mengajar, strategi bisa dihubungkan dengan polapola umum kegiatan guru anak didik dalam kegiatan belajar-mengajar untuk mencapai tujuan pembelajaran yang telah digariskan. Defenisi ini menginsyaratkan bahwa strategi memiliki peran yang sangat dominan di dalam proses pembelajaran. 
Ada empat strategi dasar dalam belajar mengajar yang meliputi hal-hal sebagai berikut :

a. Mengidentifikasi serta menetapkan spesifikasi dan kualifikasi perubahan tingkahlaku dan kepribadian anak didik sebagaimana yang diharapkan. Spesifikasi dan kualifikasi perubahan tingkah laku bagaimana yang diinginkan sebagai hasil belajar mengajar yang dilakukan itu. Disini terlihat apa yang dijadikan sebagai sasaran dari kegiatan belajar-mengajar. Sasaran yang dituju harus jelas dan terarah. Oleh karena itu tujuan pengajaran yang dirumuskan harus jelas dan konkrit, sehingga mudah dipahami oleh anak didik. Bila tidak, maka kegiatan belajar mengajar tidak punya arah dan tujuan yang pasti. Akibat selanjutnya perubahan yang dihadapi terjadi pada anak didik pun sukar diketahui karena penyimpangan-penyimpangan dari kegiatan belajar mengajar. Karena itu, rumusan tujuan yang operasional dalam belajar mengajar mutlak dilakukan oleh guru sebelum melakukan tugasnya di sekolah.

b. Memilih sistem pendekataan belajar-mengajar berdasarkan aspirasi dan pandangan hidup masyarakat. Memilih cara pendekatan belajar-mengajar yang dianggap paling efektif untuk mencapai sasaran. Bagaimana cara guru memandang suatu persoalan, konsep, pengertian dan teori apa yang dipakai dalam memecahkan suatu kasus, akan mempengaruhi hasilnya.

c. Memilih dan menetapkan prosedur, metode, dan teknik belajar-mengajar yang dianggap paling tepat dan efektif sehingga dapat dijadikan pegangan oleh guru dalam menunaikan kegiatan mengajarnya. Metode atau teknik penyajian untuk memotivikasi anak didik agar mampu menerapkan pengetahuan dan pengalamannya untuk memecahkan masalah berbeda dengan cara atau metode supaya anak didik terdorong dan mampu berpikir bebas dan cukup keberanian untuk mengemukakan pendapatnya sendiri. Perlu dipahami bahwa suatu metode mungkin hanya cocok dipakai untuk mencapai tujuan tertentu. Jadi dengan sasaran yang berbeda, guru hendaknya jangan menggunakan teknik penyajian yang sama. Bila beberapa tujuan ingin diperoleh maka guru dituntut untuk memiliki 
kemampuan tentang berbagai metode atau mengombinasikan beberapa metode yang relevan.

d. Menetapkan norma-norma dan batas-batas minimal keberhasilan atau kriteria serta standar keberhasilan sehingga dapat dijadikan pedoman oleh guru dalam melakukan evaluasi hasil kegiatan belajar-mengajar yang selanjutnya akan dijadikan umpan balik buat penyempurnaan sistem instruksional yang bersangkutan secara keseluruhan. Suatu program baru bisa diketahui keberhasilannya setelah dilakukan evaluasi. Sistem penilaian dalam kegiatan belajar mengajar merupakan salah satu strategi yang tidak bisa dipisahkan dengan strategi dasar yang lain. Apa yang harus dinilai, dan bagaimana penilaian itu harus dilakukan termasuk kamampuan yang harus dimiliki oleh guru. Seorang anak didik dapat dikatagorikan sebagai anak didik yang berhasil, bisa dilihat dari berbagai segi atau gabungan dari berbagai aspek. ${ }^{6}$

Strategi dasar dalam proses belajarmengajar seperti yang dikemukakan di atas, mengindikasikan bahwa belajar merupakan suatu kegiatan yang bersifat edukatif, sehingga nilai edukatif mewarnai interaksi yang terjadi antara guru dengan anak didik. Interaksi yang bernilai edukatif dikarenakan karena kegiatan belajar-mengajar yang dilakukan, diarahkan untuk mencapai tujuan tertentu yang telah dirumuskan sebelum pengajaran dilakukan. Guru dengan sadar merencanakan pengajarannya secara sistematis dengan memanfaatkan segala sesuatunya guna kepentingan pengajaran. Dilain sisi, harapan yang tidak pernah sirna dan selalu guru tuntut adalah bagaimana bahan pelajaran yang disampaikan guru dapat dikuasai oleh anak didik secara tuntas. Oleh karena itu, guru dituntut untuk menggunakan strategi di dalam proses pembelajaran, baik itu strategi pengorganisasian, strategi pengelolaan maupun strategi pengevaluasian.

Berkaitan dengan strategi guru di dalam pendidikan pra sekolah jalur formal atau di Taman Kanak-Kanak, salah satu faktor yang harus dikuasai oleh guru adalah bahwa masa anak-anak merupakan masa bermain, oleh sebab itu kegiatan pendidikan di Taman Kanak-Kanak harus di kemas dalam bentuk permaian atau belajar sambil bermain sebaliknya juga bermain sambil belajar. 
Dalam rangka mengembang tugas dan tanggungjawab untuk mengoptimalkan potensi kreatif yang dimiliki anak sehingga mereka dapat tumbuh dan berkembang sesuai potensi yang dimiliki maka diperlukan suatu upaya/strategi yang kreatif agar mereka dapat tumbuh secara optimal dengan kondisi nyaman dan menyenangkan.Upaya-upaya tersebut dapat dimulai dengan pemahaman para pendidik berkenaan dengan konsep dan aplikasi pengembangan kreativitas di Taman Kanak-Kanak.

\subsection{Konsep Kreativitas}

\subsubsection{Pengertian Kreativitas}

Secara alamiah perkembangan anak berbeda-beda,baik dalam bakat, minat kreativitas, kematangan emosi, kepribadian, keadaan jasmani maupun keadaan sosialnya. Selain itu, setiap anak memiliki kemampuan tak terbatas dalam belajar yang inheren(telah ada) dalam dirinya untuk dapat berpikir secara kreatif dan produktif. Anak akan beraktivitas sesuai dengan minat dan potensi yang dimiliki dirinya, pengembangan kreativitas anak harus diberikan stimulasi dari usia dini, sehingga anak akan terangsang untuk berpikir kreatif, karena dengan kreatifitaslah memungkinkan manusia menjadi berkualitas dan survive dalam hidupnya. Anak akan melihat masalah dari berbagai sudut pandang, mampu menghasilkan karya dari yang berbeda dari yang sudah ada sebelumnya.

Kreativitas sangat penting untuk dikembangkan sejak usia dini, seperti yang dikemukakan oleh Munandar bahwa :

"kreativitas yang memungkinkan manusia meningkatkan kualitas hidupnya.

Dalam era pembangunan ini, tidak dapat dipungkiri bahwa kesejahteraan dan kejayaan masyarakat dan negara bergantung pada sumbangan kreatif, berupa ide-ide baru, dan teknologi dari anggota masyarakatnya.Untuk mencapai hal itu, perlulah sikap dan perilaku kreatif dipupuk sejak dini, agar anak didik kelak tidak hanya menjadi konsumen pengetahuan baru dan pencari kerja, tetapi mampu menciptakan pekerjaan baru"7 
Uraian di atas mengandung makna bahwa kreativitas perlu dikembangkan sejak usia dini. Kreativitas merupakan kemampuan umum untuk menciptakan sesuatu yang baru, baik berupa produk atau gagasan baru, yang dapat diterapkan dalam memecahkan masalah, atau sebagai kemampuan untuk melihat unsur-unsur yang sudah ada sebelumnya.

Salah satu pendekatan yang dipakai pada anak usia dini untuk merangsang dan mengembangkan kreativitas anak adalah dengan kegiatan bermain yang dilakukan dilingkungannya, dengan menggunakan sarana, alat-alat permainan yang edukatif dan memanfaatkan berbagai sumber belajar dengan menggunakan media permainan flascard, yaitu media pembelajaran dalam bentuk kartu bergambar yang di dalamnya terdapat tulisan, gambar, atau tanda pengganti bilangan yang bervariasi. ${ }^{8}$

Utami Munandar, juga mengungkapkan tentang pengertian kreativitas dengan beberapa rumusan yang merupakan kesimpulan para ahli,antara lain:

1. Kreativitas ialah kemampuan untuk membuat komposisi baru, berdasarkan data, informasi, ataupun unsur-unsur yang ada

2. Kreativitas ialah kemampuan berdasarkan data atau informasi yang tersedia menemukan banyak kemungkinan jawaban terhadap sesuatu masalah,dimana penekanannya adalah pada kuantitas ketepatgunaan dan keragaman jawaban

3. Secara operasional kreativitas dapat dirumuskan sebagai kemampuan yang mencerminkan kelancaran, keluwesan (fleksibilitas), dan originalitas dalam berpikir, serta kemampuan untuk mengelaborasi suatu gagasan.

Pada umumnya kreativitas dirumuskan dalam istilah pribadi (person), proses (process), pendorong (press),dan produk (product).Defenisi yang menekankan pada dimensi person dikemukakan oleh Guilford, yaitu kreativitas yang mengacu pada kemampuan yang merupakan ciri/karakteristik dari orangorang kreatif.Jadi secara person, kreativitas merupakan ungkapan unik dari sebuah pribadi sebagai hasil interaksi individu, perasaan, sikap dan perilakunya. Dengan kata lain, kreativitas merupakan sifat pribadi seorang individu dan bukan merupakan sifat sosial yang dihayati oleh masyarakat, yang tercermin dari kemampuannya untuk menciptakan sesuatu yang baru. 
Defenisi yang menekankan pada proses diajukan oleh Munandar, yaitu kreativitas merupakan proses yang mencerminkan kelancaran, keluwesan maupun keaslian dalam berpikir. ${ }^{9}$ Sedangkan istilah produk,dikemukakan oleh Barron dalam Supriadi, yaitu kemampuan untuk menghasilkan sesuatu yang baru ${ }^{10}$. Menurut Hurlock, kreativitas adalah suatu proses yang menghasilkan sesuatuyang baru, apakah dalam bentuk gagasan atau objek dalam suatu bentuk atau susunan yang baru. ${ }^{11}$

Adapun pemahaman kreativitas pada produk adalah sebagai kemampuan untuk menghasilkan sesuatu yang baru.Kreativitas atau daya kreasi itu dalam masyarakat yang progresif dihargai sedemikian tingginya, dan dianggap sebegitu penting, sehingga untuk memupuk dan mengembangkannya dibentuk laboratorium atau bengkel-bengkel khusus yang tersedia tempat, waktu, dan fasilitas yang diperlukanlah dikatakan bahwa kreativitas merupakan salah.

Berdasarkan apa yang telah dikemukakan di atas dapatlah dikatakan bahwa

\subsubsection{Ciri-Ciri Kreativitas}

Berdasarkan analisis factor, Guilford mengemukakan bahwa ada lima sifat yang menjadi ciri kemampuan berpikir kreatif, yakni:

1. Kelancaran (fluency) : kemampuan untuk menghasilkan banyak gagasan

2. Keluwesan (flexibility) : kemampuan untuk mengemukakan bermacammacam pemecahan atau pendekatan terhadap masalah

3. Keaslian (originality) : kemampuan untuk memecahkan gagasan dengan cara-cara yang asli, tidak klise

4. Penguraian (elaboration) : kemampuan untuk menguraikan sesuatu dengan terperinci, secara jelas dan panjang lebar

5. Perumusan kembali (redifinition) : kemampuan untukmeninjau sesuatu persoalan berdasarkan perspektif yang berbeda dengan apa yang telah diketahui orang. ${ }^{12}$

Uraian di atas menjelaskan bahwa ciri-ciri kreativitas dapat dikelompokkan menjadi dua yaitu: ciri-ciri kreativitas yang berhubungan dengan 
kemampuan berpikir atau berpikir kreatif (berpikir divergen), ialah kemampuan menemukan banyak kemungkinan jawaban terhadap suatu masalah, yang penekanannya pada kuantitas, ketepatgunaan dan keragaman jawaban. Ciri lainnya adalah ciri yang menyangkut sikap dan perasaan yang disebut dengan ciri afektif dan kreativitas.Ciri-ciri ini merupakan ciri-ciri yang berhubungan dengan kognisi, kemampuan berpikir seseorang dengan kemampuan berpikir kreatif.

Dalam kaitannya dengan aplikasi dari wujud kreativitas pada anak usia diniadalah sebagaimana yang dikemukakan oleh Ihat Hatimah, yang mengemukakan beberapa bentuk kreativitas anak usia dini yaitu :

1. Gagasan/berpikir kreatif,yang meliputi :

a. berpikir luwes, yaitu anak yang mampu mengungkapkan pengertian lain yang mempunyai sifat sama; mampu memberikan jawaban yang tidak kaku, mampu berinisiatif

b. berpikir original yaitu anak yang mampu mengungkapkan jawaban yang baru, anak mampu mengimajinasi bermacam fungsi benda

c. berpikir terperinci, yaitu anak yang memiliki tingkat kemampuan mengingat masa lalu yang kuat, serta memiliki kemampuan menghubungkan masa lalu dan masa kini

2. Aspek sikap,yang meliputi :

a. Rasa ingin tahu, yaitu anak tersebut senang menanyakan sesuatu; terbuka terbuka terhadap situasi asing, senang mencoba hal-hal yang baru

b. Ketersediaan untuk menjawab,yaitu anak yang tertarik untuk menjawab pertanyaan-pertanyaan yang dilontarkan guru serta tertarik untuk memecahkanmasalah-masalah baru.

c. Keterbukaan, yaitu anak yang senang berargumentasi: senang terhadap pengalaman orang lain.

d. Percaya diri, yaitu anak yang berani melontarkan berbagai gagasan; tidak mudah dipengaruhi oleh orang lain; kuat pendirian, serta memiliki kebebasan berkreasi 
e. Berani mengambil resiko, yaituanak yang tidakragu mencoba hal baru, selalu berusaha untuk berhasil, dan berani mempertahankan.

3. Aspek Karya, yang meliputi :

a. permainan, yaitu anak yang berani memodifikasi berbagai mainan,mampu menyusun berbagai bentuk permainan.

b. Karangan,yaitu anak mampu menyusun karangan,tulisan atau cerita; mampu menggambar hal yang baru memodifikasi dari yang telah ada. Seorang anak yang kreatif mampu memberikan suatu pemikiran baru atau permasalahan yang dihadapi atau orang lain hadapi, baik yang berkaitan dengan kehidupan sehari-hari atau yang berkaitan dengan pengalaman uji coba. ${ }^{13}$

Ciri-ciri kreativitas seperti yang telah digambarkan di atas menunjukkan bahwa betapa sangat beragam dan fluktuatifnya kepribadian orang kreatif.Orang kreatif memiliki potensi kepribadian yang positif maupun yang negatif. Disinilah pentingnya kehadiran guru sebagai pembimbing yang akan membantu anak menyeimbangkan perkembangan kepribadiannya, sehingga anak kreatif akan berkembang optimal, tidak hanya perkembangan intelegensinya tetapi juga perkembangan sosial dan emosinya.

\subsubsection{Faktor Pendukung Kreativitas}

Kreativitas merupakan potensi yang dimiliki seseorang yang dapat dikembangkan.Dalam mengembangkan kreativitas ini terdapat faktor-faktor yang dapat mendukung upaya dalam menumbuhkembangka kreativitas. Ada berbagai pendapat yang dikemukakan oleh para ahli, salah satu diantaranya adalah Hurlock,b menurutnya, faktor pendukun kreativitas adalah :

1. Waktu. Untuk menjadi kreatif, kegiatan anak seharusnya jangan diatur sedemikan rupa sehingga hanya sedikit waktu bebas bagimereka untuk bermain dengan gagasan,konsep dan mencobanya dalam bentuk baru dan original.

2. Kesempatan menyendiri. Hanya apabila tidak mendapat tekanan dari kelompok sosial, anak dapat menjadi kreatif 
3. Dorongan terlepas dari seberapa jauh prestasi anak memenuhi standar orang dewasa

4. Sarana. Sarana untuk bermain dan kelak sarana lainnya harus disediakan untuk merangsang dorongan eksperimentasi dan eksplorasi yang merupakan unsur penting dari semua kreativitas

5. Lingkungan yang merangsang. Lingkungan sekolah dan lingkungan rumah harus merangsang kreativitas. Ini harus dilakukan sedini mungkin sejak masa bayi dan dilanjutkan hingga masa sekolah dengan menjadikan kreativitas,suatu pengalaman yang menyenangkan serta dihargai secara sosial

6. Hubungan anak dan orang tua yang tidak posesif. Orang tua yang tidak terlalu melindungi atau terlalu posesif terhadap anak, mendorong anak untuk mandiri

7. Cara mendidik . mendidik anak secara demokratis dan permisif dirumah dan di sekolah meningkatkan kreativitas

8. Kesempatan untuk memperoleh pengetahuan. Kerativitas tidak muncul dalam kehampaan, makin banyak pengetahuan yang diperoleh anak, semakin baik dasar-dasar untuk mencapai hasil yang kreatif. ${ }^{14}$

\subsubsection{Faktor Penghambat Kreativitas}

Perlu untuk diperhatikan oleh guru terutama orang tua adalah tentang berbagai sikaporang tua yang tidak menunjang kreativitas anak, seperti yang dikemukakan oleh Utami Munandar, antara lain: mengatakan kepada anak bahwa ia akan dihukum jika berbuat salah, tidak membolehkan anak menjadi marah kepada orang tua, tidak membolehkan anak mempertanyakan keputusan orang tua, tidak membolehkan anak bermain dengan yang berbeda dari keluarga anak yang pandangan dan nilai yang berbeda, anak tidak boleh berisik, orang tua ketat mengawasi kegiatan anak, orang tua memberi saran-saran spesifik tentang penyelesaian tugas. orang tua kritis terhadap anak danmenolak gagasan anak, orang tua tidak sabar dengan anak, orang tua dan anak adu kekuasaan, orang tua menekan dan memaksa anak untuk menyelesaikan tugas. ${ }^{15}$ 
Dari pemaparan di atas, dapatlah dikatakan bahwa faktor pendukung maupun penghambat kreativitas anak usia dini terletak juga pada tanggungjawab orang tua, guru serta lingkungan yang berhubungan dengan anak.

\subsection{Karakteritik Anak Usia Taman Kanak-Kanak}

Anak merupakan usia belajar yang paling potensial. Dikatakan potensial karena pada usia ini anak secara tepat dapat mengalami perubahan yang merupakan hakikat dari proses belajar-mengajar. Oleh karena itu, lingkungan pembelajaran untuk anak dapat dikembangkan.Sesuai potensi yang dimilikinya.Anak semakin menunjukan minat terhadap teman lainnya.

Menurut Snowman, anak usia pra sekolah atau TK memiliki sejumlah ciriciri yang dapat dilihat dari:

a. Ciri Fisik

Anak prasekolah umumnya sangat aktif, anak pada usia ini sangat menyukai kegiatan yang dilakukan atas kemauan sendiri. Kegiatan mereka yang dapat diamati adalah seperti suka berlari, memanjat dan melompat.Anak membutuhkan istirahat yang cukup, sulit memfokuskan pandangan pada objek-objek yang kecil ukuranya sehingga koordinasi tangan dan matanya masih kurang sempurna.

b. Ciri Social

Anak pada usia ini memiliki satu atau dua sahabat tetapi sahabat ini cepat berganti. Penyesuaian diri mereka berlangsung secara tepat sehingga mudah bergaul. Umumnya mereka sering memilih teman yang sama jenis kelamin, kemudian pemilihan jenis kelamin berkembang ke jenis kelamin yang berbeda. Anggota kelompok bermain jumlahnya kecil dan tidak terorganisir dengan baik.Oleh karena itu kelompok tersebut tidak bertahan lama dengan cepat berganti-ganti.Perselisihan sering terjadi, tetapi hanya berlangsung sebentar kemudian hubungannya berlangsung kembali. Anak usia prasekolah mempunyai kesadaran terhadap perbedaan jenis kelamin dan peran sebagai anak laki-laki dan anak perempuan. Dampak kesadaran ini mulai telihat dari pilihan terhadap alat-alat permainan. 


\section{c. Ciri Emosi}

Anak usia prasekolah cenderung mengekspresikan emosinya secara bebas dan terbuka. Ciri ini sering dilihat dari sikap marah yang sering ditunjukkannya. Sikap iri hati pada anak usia pra sekolah sering terjadi sehingga mereka berupaya untuk mendapatkan perhatian orang lain secara berebut.

\section{d. Ciri Kognitif}

Anak pra sekolah umumnya telah terampil dalam berbahasa.Pada umumnya mereka senang berbicara, khususnya dalam kelompoknya.Kompetensi anak perlu diterapkan dalam interaksi, minat, kesempatan, mengagumi, dan kasih sayang.Sebagai individu yang sementara berkembang anak memiliki sifat suka meniru tanpa mempertimbangkan kemampuan yang ada padanya.Hal ini di dorong oleh rasa ingin tahu dan ingin mencoba sesuatu yang diminati, yang kadangkala muncul secara spontan sikap jujur yang menunjukkan kepolosan seseorang. Kehidupan yang dirasakan anak merupakan sosok individu yang kompleks yang memiliki perbedaan dengan individu lainnya. Pemahaman guru tentang karakteristik anak akan bermanfaat dalam upaya menciptakan lingkungan belajar yang mendukung perkembangan anak.

\subsection{Karakteristik dan Kepribadian Guru Pengembang Kreativitas}

Untuk membantu anak tetap memiliki dan mengembangkan potensi kreatifnya, dibutuhkan seorang guru yang memiliki karakteristik sebagai berikut: kreatif dan meyukai tantangan, menghargai karya anak, menerima anak apa adanya, motivator, ekspresif, penuh penghayatan dan peka pada perasaan, pencinta seni dan keindahan, memiliki kecintaan yang tulus kepada anak, memiliki ketertarikan terhadap perkembangan anak, bersedia memiliki potensi yang dimiliki anak,hangat dalam bersikap, memiliki sikap yang konsisten akan tetapi dinamis, bersedia bermain dengan anak, luwes dan lincah dalam kebutuhan, minat dan kemampuan anak, memberikan kesempatan kepada anak untuk 
menjelajahi lingkungan, memberi kesempatan kepada anak untuk mencoba dan mengembangakan kemampuan, daya pikir serta daya ciptanya. ${ }^{16}$ Karakteristik dan kepribadian guru sebagaimana yang telah diutarakan di atas, memang benar adanya. Hal ini diakibatkan karena pada dasarnya setiap anak memiliki kecenderungan berbakat dalam dan memiliki kemampuan mengungkapkan dirinya secara kreatif, meskipun masing-masing anak

Ada tujuh strategi yang dapat digunakan oleh guru untuk meningkatkan kreativitas anak usia dini khususnya anak usia Taman Kanak-Kanak, antara lain :

1. Pengembangan kreativitas melalui menciptakan produk (Hasta Karya)

Memiliki posisi penting dalam berbagai aspek perkembangan anak. Tidak hanya kreativitas yang akan terfasilitasi untuk berkembang dengan baik, tetapi juga kemampuan kognitif anak. Dalam kegiatan hasta karya, setiap anak akan menggunakan imajinasinya untuk membentuk suatu bangunan atau benda tertentu berdasarkan khayalan imanjinasinya.

2. Pengembangan kreativitas melalui imajinasi

Janis Beaty menyatakan bahwa bagi anak imajinasi adalah kemampuan anak untuk merespons atau melakukan fantasi yang mereka buat dan kebanyakan anak dibawah usia tujuh tahun melakukan hal tersebut. Dalam permainan imajinasi anak dapat memperagakan sesuatu situasi, memainkan perannya dengan cara tertentu ataupun membayangkan situasi yang tidak pernah mereka alami.

3. Pengembangan kreativitas melalui eksplorasi

Ide kreatif sering kali muncul dari eksplorasi atau penjelajahan individu terhadap sesuatu.Eksplorasi dapat memberikan kesempatan kepada anak untuk melihat, memahami dan merasakan dan pada akhirnya membuat sesuatu yang menarik perhatian mereka.Kegiatan eksplorasi adalah penjelajahan lapangan dengan tujuan memperoleh pengetahuan lebih banyak terutama sumber alam yang ada di tempat itu.

4. Pengembangan kreativitas melalui eksperimen

Eksperimen atau percobaan pada anak usia dini atau taman kanak-kanak yang dimaksud dalam hal ini bukanlah suatu proses rumit yang harus dikuasai anak 
sebagai suatu cara untuk memahami konsep tentang sesuatu hal ataupun penguasaan anak tentang konsep dasar eksperimen, melainkan pada bagaimana mereka dapat mengetahui cara atau proses terjadinya sesuatu, dan bagaimana sesuatu dapat terjadi dan bagaimana mereka dapat menentukan solusi terhadap permasalahan yang ada dan pada akhirnya mereka dapat membuat sesuatu yang bermanfaat bagi kegiatan tersebut.

5. Pengembangan kreativitas melalui proyek Metode proyek merupakan metode pembelajaran yang dilakukan anak untuk melakukan pendalaman terhadap sutau topik pembelajaran yang diminati oleh satu atau beberapa anak, yang dikerjakan secara berkelompok untuk memecahkan masalah yang dihadap kelompok untuk mencapai tujuan.

6. Pengembangan kreativitas melalui musik

Ungkapan diri kreatif berkaitan dengan musik pada anak taman kanak-kanak masih sangat sederhana, seperti: memperagakan gerakan yang khas untuk melukis nyanyian, memainkan alat musik perkusi makin keras atau makin lunak dengan maksud menambahkan nuansa tertentu, mungkin juga mengarang syair yang baru untuk nyanyian yang sudah dikenal.

7. Pengembangan kreativitas melalui bahasa

Bahasa merupakan kemampuan untuk berkomunikasi dengan orang lain. Sering kali ditemukan anak-anak taman kanak-kanak berbicara, mereka sering berbicara tentang apa yang terjadi baik pada dirinya sendiri maupun pada orang lain. Mereka sering berbicara untuk mengeluarkan apa yang ada dalam pikiran mereka. Sikap ini mendorong meningkatkan penggunaan bahasa dan dialog dengan yang lain. Sebagian anak juga terlihat mengalami kesulitan mengungkapkan perasaan dengan kata-kata dan menunjukkannya dengan perbuatan. $^{17}$

Jadi, jelas bahwa sesungguhnya tidak ada seorangpun yang tidak memiliki bakat kreatif, namun apabila tidak dipupuk atau dikembangkan maka bakat ini tidak akan berkembang secara optimal. Ditinjau dari segi pendidikan, bakat kreatif ini dapat ditingkatkan, oleh karena itu perlu dipupuk sejak dini, sehingga yang 
diperlukan sekarang ialah bagaimana caranya meningkatkan kreativitas anak usia dini.

Selain itu juga ada salah satu upaya dalam mengembangkan kreativitas anak Taman Kanak-Kanak adalah dengan memberikan stimulus yang baik dan tepat, yaitu pembelajaran dengan bermain.Dimana setiap materi yang akan diberikan harus dikemas dalam bentuk permainan. Permainan merupakan kegiatan yang menyenangkan dilakukan oleh anak, dengan permainan anak dapat melakukan banyak hal, anak akan mendapatkan informasi atau pengetahuan yang belum diketahuinya, sehingga anak akan berpikir kreatif untuk memasuki lingkungan bermainnya. Perlu dijelaskan bahwa ada begitu banyak permainan yang terdapat dalam tujuh strategi untuk mengembangkan kreativitas anak usia dini, terdapat \pm 93 permainan/kegiatan ${ }^{18}$ yang tersebar dalam tujuh strategi pengembangan kreativitas sebagaimana yang telah dijelaskan. Ini berarti guru Tamak Kanak-Kanak hendaknya memiliki jiwa kreatif dan bersedia menerima berbagai potensi yang dimiliki oleh anak sehingga anak dapat mengembangkan kreativitas yang dimilikinya secara terbuka.

\section{PENUTUP}

Dalam rangka mewujutkan tatanan pendidikan yang mandiri dan berkualitas sebagaimana diatur dalam UU No. 20 Tahun2003 tentang sistim Pendidikan Nasional, perlu dilakukan berbagai upaya strategis dan integral yang menunjang penyelenggaraan.Kesempatan memperoleh pendidikan yang berkualitas berlaku untuk semua (education for all), mulai dari usia dini sebagai masa the golden age sampai jenjang pendidikan tinggi. Mengacu pada hal tersebut, proses pembelajaran pada anak usia dini hendaknya diberikan dengan tujuan untuk memberikan konsep-konsep dasar yang memiliki kebermaknaan bagi anak melalui pengalaman nyata yang memungkinkan anak untuk menunjukkan aktivitas dan ras ingin tahu secara optimal. Proses pembelajaran seperti ini memungkinkan adanya keseimbangan peran dan pola asuhan pendidik yang 
demokratis agar anak memiliki kebebasan untuk mengeksplorasi dunia sekitar. Salah satu cara yang harus ditempuh oleh guru adalah dengan menggunakan strategi dalam proses belajar-mengajar agar kreativitas anak dapat dieksplor untuk dikembangkan.

\section{Catatan akhir}

${ }^{1}$ Yeni Rahmawati \& Euis Kurniawati, Strategi Pengembangan Kreativitas Pada Anak Usia Taman Kanak-Kanak. Kencana: Jakarta 2010, hal 1

2 Tangyong Agus F, dkk, CBSA: Pengembangan Anak Usia Taman Kanak-Kanak . Suatu Panduan bagi Guru Taman-Kanak-Kanak untuk Menyusun Persiapan bagi Kegiatan BelajarMengajar. Jakarta, Gramedia, hal 21

${ }^{3}$ Yuliani Nurani Sujiono, 2009, Konsep Dasar Pendidikan Anak Usia Dini,Jakarta, Indek, hal 8.

${ }^{4}$ Undang-Undang No 20 Tahun 2003 Tentang Sistim Pendidikan Nasional,

${ }^{5}$ Tuhana Taufig Adrianto, 2013, Cara Cerdas Mengaktifkan IQ Kreatif Anak, Jogjakarta,Kata Hati, h. 86

${ }^{6}$ Syaiful Bahri Djamarah \& Aswan Zain, Strategi Belajar-Mengajar, Rineka Cipta :Jakarta, cet 5, h. 5-8.

${ }^{7}$ Utami, Munandar, 1999, Kreativitas dan Keberbakatan. Strategi Mewujudkan Potensi Kreatif dan Bakat, Jakarta : Grasindo, h 44

${ }^{8}$ Ahmad Susanto, 2012, Perkembangan Anak Usia Dini, Pengantar dan Berbagai Aspeknya, Edisi Kedua, Kencana Prenada media Group, Jakarta, h,

${ }^{9}$ Munandar dalam Susanto, Opcit

10 Barron dalam Semiawan, Conny,Belajar Dan Pembelajaran Dalam Taraf Usia Dini: Pendidikan Prasekolah Dan Dasar, Jakarta : Prenhalindo, 2002, hal 10

${ }^{11}$ Hurlock Dalam Susanto, Psikologi Perkembangan Suatu PendekatanSepanjang Rentang Kehidupan(Terj), Jakarta, Erlangga, 1999, h. 32

${ }^{12}$ Guilford dalam Jamaris M, 2002, Perkembangan dan Pengembangan Anak Usia Taman KanakKanak, Pedoman Bagi Orang Tua dan Guru,Jakarta : Grasindo, hal 67.

13 Jamaris M, 2002, Perkembangan dan Pengembangan Anak Usia Taman Kanak-Kanak, Pedoman Bagi Orang Tua dan Guru, Jakarta : Grasindo, hal 44

${ }_{14}$ Hurlock, 1999, Psikologi Perkembangan Suatu Pendekatan Sepanjang Rentang Kehidupan(Terj), Jakarta, Erlangga, h. 11

${ }^{15}$ Munandar Utami,Kreativitas Dan Keberbakatan. Strategi Mewujutkan Potensi Kreatif Dan Berbakat,Jakarta : Gramedia Pustaka Utama. 1999,h.95

${ }^{16}$ Yeni Rahmawati \& Euis Kurniawati, Strategi Pengembangan Kreativitas ,... h.45-50

${ }^{17}$ Yeni Rahmawati \& Euis Kurniati, Strategi Pengembangan Kreativitas, ... h.52-65

${ }^{18}$ Yeni Rahmawati \& Euis Kurniati, Strategi Pengembangan Kreativitas, ... h. 67-174 


\section{DAFTAR PUSTAKA}

Adrianto Taufig Tuhana, 2013, Cara Cerdas Mengaktifkan IQ Kreatif Anak, Jogjakarta : Kata Hati

Agus F Tangyong, dkk, 2011, CBSA: Pengembangan Anak Usia Taman Kanak-Kanak .

Suatu Panduan bagi Guru Taman-Kanak-Kanak untuk Menyusun Persiapan bagi

Kegiatan Belajar-Mengajar. Jakarta, Gramedia

Djamarah Syaiful Bahri \& Zain Aswan, 2012, Strategi Belajar-Mengajar, Rineka Cipta : Jakarta, cet 5

Hurlock, E. B, 1999, Psikologi Perkembangan Suatu Pendekatan Sepanjang Rentang Kehidupan(Terj), Jakarta, Erlangga

Jamaris M, 2002, Perkembangan dan Pengembangan Anak Usia Taman Kanak-Kanak, Pedoman Bagi Orang Tua dan Guru, Jakarta : Grasindo

Munandar Utami 1999, Kreativitas Dan Keberbakatan. Strategi Mewujutkan Potensi Kreatif Dan Berbakat,Jakarta : Gramedia Pustaka Utama.

Rahmawati Yeni \& Kurniawat Euis, 2010, Strategi Pengembangan Kreativitas Pada Anak Usia Taman Kanak-Kanak. Kencana: Jakarta

Sujiono Nurani Yuliani, 2009, Konsep Dasar Pendidikan Anak Usia Dini,Jakarta, Indek

Susanto Ahmad, 2012, Perkembangan Anak Usia Dini, Pengantar dan Berbagai Aspeknya, Edisi Kedua, Kencana Prenada media Group, Jakarta

Semiawan Conny, 2002, Belajar Dan Pembelajaran Dalam Taraf Usia Dini: Pendidikan Prasekolah Dan Dasar, Jakarta : Prenhalindo

Undang-Undang No 20 Tahun 2003 Tentang Sistim Pendidikan Nasional. 